\title{
CONSTRUCCIONS CONNECTIVES BINÀRIES EN EL DEBAT PARLAMENTARI*
}

\author{
BINARY CONNECTIVE CONSTRUCTIONS \\ IN PARLIAMENTARY DEBATE
}

\author{
MarTí Mestre \\ Universitat de Zadar \\ marmesme@alumni.uv.es
}

Resum: El gènere polític del debat parlamentari és eminentment argumentatiu perquè els parlamentaris defensen una postura respecte a un tema de discussió. Aquesta postura es materialitza en unes estructures argumentatives, les parts de les quals sovint són delimitades pels connectors binaris (principalment causals i consecutius, però també condicionals, finals, adversatius i concessius). L'objectiu d'aquest treball és fer una anàlisi lingüística i argumentativa d'aquest tipus de construccions des d'una perspectiva local, cas per cas, i global, integrades en l'encadenament discursiu, en un corpus format per tres debats en català del Parlament de Catalunya. D'una banda, a partir dels resultats obtinguts, s'hi fa una comparació amb els resultats de treballs anteriors que tracten de la relació entre connexió i gènere discursiu (Castellà 200I; Cuenca 2013a) i es relaciona l'ús de connectors amb el grau de formalitat i preparació del debat parlamentari. D'una altra banda, s'hi analitza la construcció del discurs i l'estil individual de cada parlamentari d'acord amb l'encadenament i la coherència de les idees, i al tipus d'ordre i moviment argumentatius.

Paraules clau: Relacions binàries, construccions connectives binàries, argumentació, debat parlamentari, gènere discursiu.

Abstract: Parliamentary debate is essentially an argumentative genre because members of parliament defend a stance regarding a topic of discussion. This position is embodied in argumentative

$\left.{ }^{*}\right)$ Vull agrair a la Dra. M. Josep Cuenca els comentaris i suggeriments sempre encertats en la tutorització i el guiatge d'aquesta recerca, l'origen de la qual és el treball de fi de màster "Construccions connectives binàries en el debat parlamentari» (2014) del Màster en Assessorament Lingüístic i Cultura Literària. 
Martí Mestre

Construccions connectives binàries en el debat parlamentari

structures, parts of which are often defined by binary connectives (mostly causal and consequence, but also conditional, final, adversative and concessive). The aim of this paper is to analyse such constructions both linguistically and argumentatively in a corpus composed of three debates in Catalan taking place in the Parliament of Catalonia. The analysis is made both from a local perspective (case by case) and from a global perspective (each case integrated into the discursive chain). Firstly, our data are compared with the results of previous studies dealing with the relationship between discursive genre and the use of connectives (Castellà 200I; Cuenca 20I3a). Secondly, the relationship between the uses of connectives and the degree of formality and preparation of parliamentary debate is discussed. Finally, the discourse construction and individual style of each Member of Parliament is analysed according to chain and coherence relationships as well as in terms of the type of argumentative order and movement.

Key words: Binary relations, connective binary constructions, argumentation, parliamentary debate, discursive genre.

\section{$\operatorname{cosects}$}

\section{INTRODUCCIÓ}

En aquest treball s'analitzen les construccions connectives binàries causals, consecutives, condicionals, finals, adversatives o de contrast i concessives, presents en tres debats en català sobre el dret a decidir del Parlament de Catalunya. Concretament, ens centrarem en els connectors que les identifiquen en relació amb el gènere i la formalitat, $i$ en les estructures resultants, que funcionen com a mecanisme argumentatiu en el discurs. Per a dur-ho a terme, es pretén descriure l'ús, el funcionament i les regularitats d'aquests connectors, i veure com contribueixen a l'encadenament argumentatiu, per tal d'avaluar la manera d'argumentar dels parlamentaris.

El corpus que hem fet servir conté tres parts de debats del Parlament de Catalunya. ${ }^{1}$ La primera part és sobre la proposta de sobirania de Catalunya, que va tenir lloc el dia 23 de gener de 2013 i consta de 13738 mots, dels quals 208 són connectors

I. Els debats pertanyen a la x legislatura de govern (des del 17 de desembre de 2012 fins al 4 d'agost de 20I5), integrada pels partits següents: Convergència i Unió (CIU, 50 escons), Esquerra Republicana de Catalunya (ERC, 2I escons), Partit Socialista de Catalunya (PSC, 20 escons), Partit Popular de Catalunya (PPC, I9 escons), Iniciativa per Catalunya-Els Verds (ICV, I3 escons), Ciutadans (C's, 9 escons) i Candidatura d'Unitat Popular (CUP, 3 escons). Per a informació detallada sobre el funcionament del Parlament de Catalunya, consulteu: <http://www.parlament.cat/web/parlament/funcions/funcio-legislativa> i <http:/www.parlament.cat/ web/parlament/estructura/treball> 
binaris; la segona part és sobre la proposta de diàleg amb l'Estat sobre el dret a decidir, que va tenir lloc el dia I3 de març de 2013 i conté 9988 mots, dels quals I72 són connectors binaris; i la tercera part és sobre la proposta de llei de consultes, del dia I6 de gener de 20I4, i consta de 15036 mots, dels quals 248 són connectors binaris. Els tres textos han estat seleccionats perquè tracten del mateix tema, el dret a decidir, que requereix una postura ferma des de l'inici i relativament inalterable en el temps.

Com a passa prèvia a l'anàlisi, hem extret tots els casos de relacions binàries explicitades pels connectors en el corpus d'anàlisi, i els hem introduït en una taula ordenats segons el valor semàntic (causals, consecutius, condicionals, finals, concessius $i$ adversatius), la categoria, el nivell oracional o textual i, a més, hem fet una paràfrasi de la construcció per facilitar-ne l'anàlisi. En el procés, hem tingut en compte tant el vídeo del debat com la transcripció del text. A banda, hem seleccionat un fragment representatiu de cada parlamentari i n'hem fet un esquema de les idees a partir dels connectors emprats, per poder establir el tipus d'encadenament argumentatiu.

Hi ha molts treballs que han estudiat el debat parlamentari, tant amb propòsits teòrics com aplicats (Van Dijk 2000, 2002; Ilie 2003, 2006; Bayley (ed.) 2004; Marafioti, 2007; Cuenca 20I4; Cuenca i Mestre 20I5). En el nostre cas, focalitzem l'estudi en un aspecte lingüístic, les construccions connectives binàries, i les analitzem des de diverses perspectives, partint de treballs estrictament lingüístics (Cuenca I99ra, I99Ib, 2006), d'estudis de l'argumentació rellevants per a l'objecte d'estudi (Moeschler 1985; Adam 1992) i de treballs més aplicats sobre els connectors i el gènere discursiu (Castellà 200I, 2004; Cuenca 20I3a).

A través de l'estudi de les construccions connectives binàries, hem pogut comprovar com, en general, el debat parlamentari s'aproxima a gèneres discursius intermedis entre l'oral i l'escrit com, per exemple, la classe magistral. Tanmateix, cal tenir en compte l'estil de cada persona. A més, hem comprovat que les relacions binàries de causa i de contrast són majoritàries en el debat, atès que els parlamentaris fonamentalment han de justificar la seua postura respecte al tema de debat i també han de rebatre les opinions dels altres amb contraarguments.

\section{LES RELACIONS BINÀRIES}

Les relacions binàries generen unes estructures oracionals compostes de dues unitats que mantenen una relació d'interdependència semàntica, i que tenen una funció argumentativa en el discurs (Cuenca 1991b, 1995). Aquestes oracions poden 
Martí Mestre

Construccions connectives binàries en el debat parlamentari

contenir un connector ${ }^{2}$ que explicita la relació sintàctica, semàntica i/o pragmàtica existent prèviament entre els dos membres (Cuenca 2006 2013). Segons la classificació de Cuenca (2006: IIO), aquest tipus de construccions, a més, manifesten una asimetria d'origen semàntici no sintàctic, sovint són reversibles, poden presentar una recursivitat cíclica i expressen significats de tipus causatiu. Per això, alguns estudiosos defensen l'existència d'un grup intermedi d'oracions compostes, respecte de la divisió tradicional en coordinades i subordinades: les anomenades bipolars (Rojo 1978) o interordinades (Cuenca 1988, I991a, I99Ib, 2006). Aquest tipus d'oracions també s'ha tractat sota els termes d'adverbials impròpies, adverbials no circumstancials, adverbials que funcionen com a adjunt oracional, etc. En resum, la relació que manifesten aquest tipus de construccions és binària $\mathrm{i}$, doncs, no és ni serial, com en el cas de la coordinació, ni de dependència sintàctica, com en el cas de la subordinació.

\section{I RELACIONS BINÀRIES: COHERÈNCIA I ESTRUCTURA SEMÀNTICA}

Les relacions binàries són clau per a l'estudi de la coherència d'un discurs, especialment quan un connector les explicita. Per això, com apunta Degand (I998: 29), hi ha molts treballs que intenten establir el lligam entre les relacions de coherència $i$ els connectors, sobretot amb els binaris o interordinants: «it seems plausible to accept that inter-clausal connectives always mark (at least) a coherence relation» (1998: 30). De manera semblant, hi ha molts estudis dedicats a les relacions binàries de caràcter asindètic, especialment referides a la causalitat en sentit extens (Gohl 2000; Sanders \& Spooren 2009; Corminbreuf 20I0). És interessant destacar l'estudi de Sanders i Spooren (2009), perquè presenta un llistat de possibilitats semàntiques de les relacions de coherència en el discurs, encara que no necessàriament marcades per connectors, com, per exemple: causa/conseqüència, causa / conseqüència contrastiva, argument/afirmació, instrument/propòsit, condició/conseqüència i argument / afirmació contrastiva.

En el nostre cas, seguim la proposta de Cuenca (2006: III), segons la qual les relacions binàries expressen significats de tipus causatiu i, seguint López (1983), indica que es relacionen de dos en dos, perquè manifesten relacions complementàries. Així, n'hi ha de dos tipus: d'una banda, les causals, condicionals i concessives, on el nexe destaca l'origen de la relació, la causa, com ocorre en (I).

2. En el present treball, seguim la distinció categorial dels connectors establerta en Cuenca (2006, 2013b), segons la qual la conjunció és la categoria prototípica en el nivell oracional i el connector parentètic en el nivell textual. No obstant això, les dues categories poden funcionar tant en un nivell com en l'altre. 
(I) I com que el Govern espanyol ha negat reiteradament fins ara el dret a decidir, el nostre futur, no podem deixar de preguntar-nos què farem després d'intentar dialogar tantes vegades com sigui possible. (Rovira, ERC, $\left.\mathrm{D}_{2}\right)^{3}$

En aquest exemple, hi ha una relació binària de causa real / efecte real, on es destaca l'origen de la relació «la negació del dret a decidir per part del Govern espanyol», introduït per com que.

D'una altra banda, hi ha les consecutives, finals i adversatives, on el nexe destaca la fi de la relació, l'efecte, com en (2).

(2) No és una competència autonòmica $i$, per tant, incompleix la mateixa llei autonòmica. (Sánchez-Camacho, PPC, D3)

L'exemple de (2) manifesta una relació binària d'efecte real / causa real, on es destaca la fi de la relació «incomplir la llei autonòmica», que és introduïda per $i$, per tant. En la figura I, veiem una síntesi de totes les possibilitats de relacions binàries tant en el nivell oracional com en el textual. No hi hem inclòs les comparatives perquè no contribueixen de manera tan clara a l'argumentació.

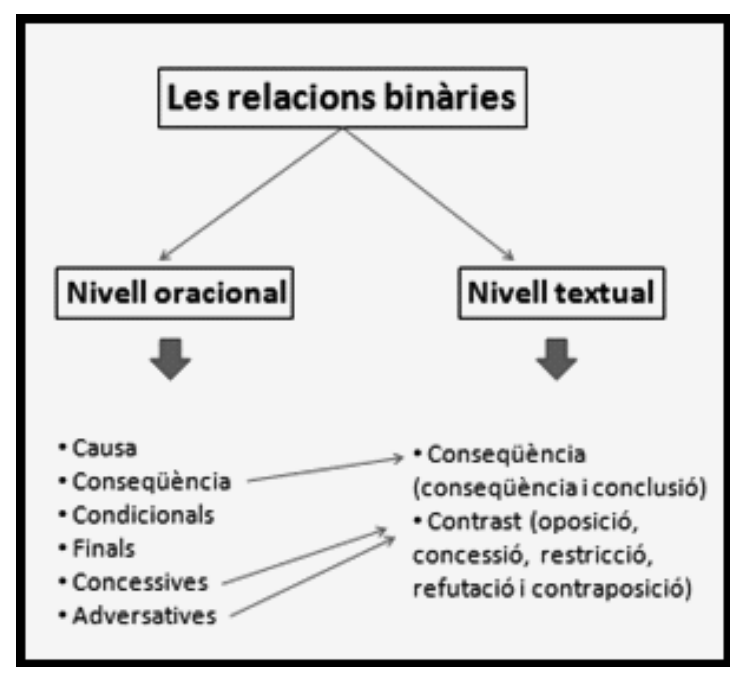

Figura I. Tipus de relacions binàries

3. El parèntesi de cada exemple conté el nom del parlamentari, el partit polític i el debat a què pertany. 
Martí Mestre

Construccions connectives binàries en el debat parlamentari

Com apunta la figura I, partim d'una concepció semàntica de les relacions binàries, la qual cosa permet equiparar el tipus de relacions que tenen lloc en el nivell intraoracional i en l'extraoracional. Cal tenir en compte que, per a l'anàlisi del discurs, el fet que el nivell de connexió siga oracional o textual té una importància relativa, sobretot si, com en el nostre cas, el discurs és oral i la transcripció és sempre un criteri de classificació relatiu.

Les sis possibilitats de binarietat semàntica basades en l'esquema causa/efecte i tesi/antítesi marcades per un connector permeten introduir els arguments, contraarguments i les opinions.

\subsection{RELACIONS BINÀRIES: ARGUMENTACIÓ}

Els connectors que delimiten relacions binàries han estat estudiats per alguns teòrics de l'argumentació o del discurs (Toulmin 1958; Van Dijk I978; Anscombre \& Ducrot 1983, 1989; Anscombre 1989a, I989b; Moeschler 1985, 1989, 2015; Adam 1992; Cuenca 1995; Bassols \& Torrent 1996; Ellerup Nielsen 1996; Calsamiglia \& Tusón 1999; Besa 20I4). En el nostre cas, ens interessen les propostes de Moeschler (1985) i d'Adam (1992), perquè consideren els connectors com les peces clau per a organitzar les estructures argumentatives. Moeschler sosté que un discurs (D) és argumentativament coherent si «les instructions argumentatives posées par les connecteurs argumentatifs sont satisfaites en $\mathrm{D}$ » $\mathrm{i}$ «toute contradiction argumentative est résolue dans le mouvement discursif qui génère $\mathrm{D}$ » (1985: 130). Com veiem, introdueix la noció de moviment discursiu, que és la manera com s'organitza el discurs argumentatiu. Distingeix tres tipus de moviments: l'opositiu (amb connectors de contrast com però), el conclusiu (amb connectors introductors de conclusions com en definitiva) i el consecutiu (amb connectors consecutius com per tant).

Adam (1992) ens proposa un model argumentatiu que redefineix la teoria de Toulmin (1958) i ens resulta útil per a fer una anàlisi extensa de les relacions de coherència en els textos argumentatius. L'autor considera que tota seqüència argumentativa (figura 2) és composta bàsicament d'unes dades o fets (les premisses), un apuntalament (étayage) i una conclusió assertiva (I992: I45). La figura 2 mostra el model de l'encadenament argumentatiu proposat per Adam. 


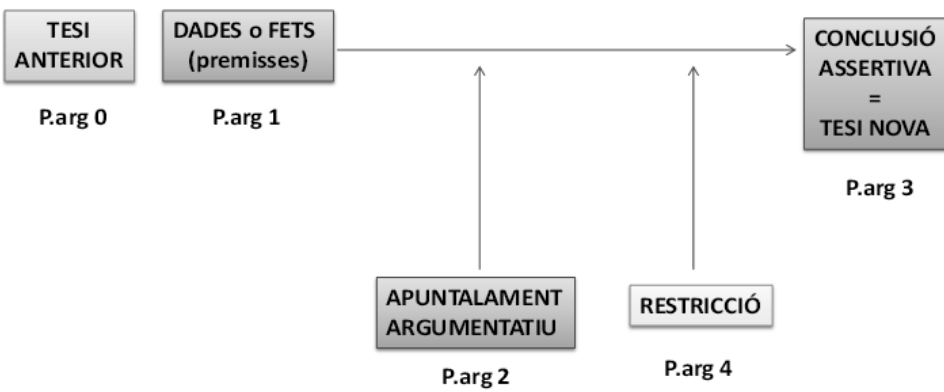

Figura 2. Model de l'encadenament argumentatiu d'Adam (1992: I46)

En el model d'Adam, hi ha 5 macroproposicions argumentatives: P.arg I, P.arg 2 i P.arg. 3, que pertanyen al nivell justificatiu; i P.arg o i P.arg 4, que pertanyen al nivell dialògic o contraargumentatiu. Un dels conceptes interessants és la categoria de tesi anterior, que és el suport, en el cas de la refutació, de les macroproposicions I, 2 i 3. Finalment, Adam comenta que l'esquema no ha de seguir necessàriament l'ordre establert, ja que la tesi nova pot aparèixer d'entrada i reformular-se o no al final, i la tesi anterior pot ser sobreentesa.

Adam (1992: 134) també proposa dues formes de classificar lògicament l'ordre argumentatiu: (a) l'ordre regressiu, que és el de la prova i l'explicació i conté un connector causal que introdueix l'argument; i (b) l'ordre progressiu, que ve a concloure, $\mathrm{amb}$ un connector consecutiu. En (3), hi ha una estructura regressiva perquè primerament va la tesi i després l'argument. En (4), hi ha una estructura progressiva perquè primerament va l'argument i després la tesi.

(3) Aquest és un text satisfactori, perquè obre el procés sense apriorismes. (Herrera, ICV, DI)

(4) S'ha renunciat a ni tan sols anomenar el marc complet de la nació catalana, els Països Catalans. Per tant, ens retallem a nosaltres mateixos, d'entrada, la nació. (Arrufat, CUP, Di)

Keren-Portnoy, Parush i Schlesinger (200I: 8$)^{4}$ també recullen el concepte d'ordre argumentatiu quan diferencien mode progressiu i mode regressiu. En aquest cas, però, ho fan des de la perspectiva del procés de raonament previ de les argumentacions.

4. Aquests autors estudien l'ordre argumentatiu tenint en compte el procés previ a la formalització verbal i afirmen que el fet que una estructura siga formulada lingüísticament en un mode progressiu o regressiu no significa que s'haja seguit el mateix procediment en el procés de raonament previ, perquè un individu pot analitzar unes dades i extreure'n una conclusió (raonant en mode progressiu), però pot formalitzar-ho en un mode regressiu, partint de la conclusió (2001: 9). 
Martí Mestre

Construccions connectives binàries en el debat parlamentari

De manera semblant, Sanders i Spooren (2009: 207) tracten d'aquest concepte, però en relació amb el tipus de construccions causals: forward o backward causality.

Lordre argumentatiu d'Adam té relació amb la noció de moviment argumentatiu de Moeschler, perquè les dues concepcions són formes paral-leles de classificar la direcció i l'organització que tenen les estructures argumentatives. Ara bé, Moeschler no hi inclou el moviment de tipus deductiu, amb els connectors causals, que és bàsic en qualsevol argumentació, sobretot l'oral. Moeschler (1985: 134) ho justifica afirmant que aquestes seqüències justificatives o explicatives no apareixen en la dimensió del procés de l'activitat argumentativa ni en la noció de càlcul; per tant, no es poden considerar pròpiament moviments argumentatius. Tanmateix, Keren-Portnoy, Parush i Schlesinger (200I: 80) sí que consideren que la justificació i l'explicació són operacions argumentatives, ja que es produeix un procés de raonament invertit o de tornada, en comparació amb el mode progressiu.

Adam, seguint Apothéloz i Miéville (1989: 249), afirma que l'ordre regressiu és més propi de l'argumentació oral perquè és més pròxim a l'ordre cronològic de l'enunciació, ja que s'introdueix una opinió i després es justifica o s'explica.

Un altre dels conceptes interessants d'Adam per a l'anàlisi de la coherència en l'argumentació és l'apuntalament argumentatiu o loi de passage, que són els principis que legitimen els arguments (fets, valors, normes, etc.) i la seua base de suport. ${ }^{5}$ Gràcies a aquest apuntalament, el receptor pot establir lligams entre situacions expressades en una estructura argumentativa (Ellerup Nielsen 1996: 330) i, doncs, establir la base de les relacions de coherència d'un discurs.

\subsection{RELACIONS BINÀRIES: CONNEXIÓ I DEBAT PARLAMENTARI}

Les relacions binàries marcades per un connector permeten mesurar el nivell de cohesió d'un text i el grau de coherència de les idees que hi són presents. Però, a més, poden servir com a indicador del mode, oral o escrit, i fins i tot del gènere discursiu. En el nostre treball, analitzem el gènere del debat parlamentari, que té unes característiques intermèdies: és un text oral formal que té una preparació prèvia per escrit, de manera que participa tant de l'escriptura com de l'oralitat (Cuenca 20I4: 733).

D’acord amb Van Dijk (2000: 53), el debat parlamentari es pot definir com:

5. Aquest concepte ha estat treballat per altres estudiosos de l'argumentació amb una altra nomenclatura: garantia dels arguments (warrant) i la base de suport (backing) (Toulmin 1958), la legitimitat i les circumstàncies (Van Dijk 1978) i els topoi (Ducrot 1984; Moeschler 1985). 


\begin{abstract}
A formal gathering of a group of elected representatives, members of various political parties, engaging in a discussion about what collective action or policy to undertake concerning an issue of public concern.
\end{abstract}

Qualsevol discussió presenta, com a mínim i a la bestreta, dues postures respecte a un tema i dos actors que representen aquestes posicions. Aquests actors hauran de defensar la seua opinió a través d'unes estructures argumentatives, integrades per arguments i, en alguns casos, per contraarguments. A més, aquestes estructures parteixen de relacions binàries que sovint s'expliciten, com hem dit, a través dels connectors anomenats argumentatius.

Aquest gènere, a més, té una estructura dialògica basada en la juxtaposició de monòlegs (Cuenca 20I4: 733) i un caràcter deliberatiu, ja que els parlamentaris han d'avaluar els avantatges o inconvenients de la proposta del debat i prendre-hi una decisió en termes de vots (Ilie 2006: 190). Tanmateix, sovint es pot intuir el resultat de la votació amb antelació perquè es coneixen les postures dels partits polítics respecte a la proposta i, doncs, els parlamentaris es limiten a justificar la seua opinió, en lloc d'argumentar i convèncer l'adversari (Marafioti 2007: 108).

Com es pot comprovar, el debat parlamentari està definit, sobretot, per la relació entre el gènere discursiu i el mode en què es realitza. Per aquest fet, és interessant comparar i contrastar els resultats del present treball amb estudis que posen de manifest la relació entre les característiques del gènere discursiu i els connectors que hi apareixen, com els de Castellà (200I) i Cuenca (2013a).

Castellà (200I, 2004) elabora un estudi de la complexitat lingüística en el discurs oral i escrit a partir de l'anàlisi comparativa de tres gèneres discursius en llengua catalana que serveix per a descriure el contrast lingüístic entre l'oralitat i l'escriptura: la conversa informal, paradigma de l'oralitat; la prosa acadèmica, paradigma de l'escriptura, i la classe magistral, gènere intermedi, per tal com és oral però està influït per l'estil propi de l'escrit. En especial, convé destacar l'estudi i l'anàlisi del nombre de construccions interordinades presents en aquests tres gèneres perquè, atès que segueix la proposta de Cuenca (I988, I99Ia, I99Ib), podem establir una comparació quantitativa amb les dades que hem extret del nostre debat d'anàlisi. A més, l'autor afirma que «en els gèneres orals es tendeix a manejar un nombre més reduït d'elements lingüístics que, lògicament, resulten ser més polivalents» (200I: 622); o siga, hi ha una varietat reduïda de connectors amb comportaments diversos.

En aquesta línia, Cuenca (20I3a) analitza les construccions causals en tres gèneres del discurs oral amb diferències de registre (el debat polític, la conversació $\mathrm{i}$ l'entrevista). La comparació entre els diversos gèneres atenent als connectors apareguts

Caplletra 60 (Primavera, 2016), pp. 83-111 
i al significat de les causals, posa de manifest de quina manera la formalitat del gènere influeix en l'ús dels connectors i el tipus de construccions predominants. Els resultats d'aquest treball coincideixen amb els de Castellà (200I, 2004), perquè mostren que les construccions causals en gèneres orals, en comparació amb els escrits, «exhibit a reduced variety of markers but a wider variety of structures and meanings» (Cuenca 2013: I8). En altres paraules, hi ha pocs tipus de connectors (perquè i com que), però aquests presenten comportaments diversos: especialment, hi destaca perquè, que és el més freqüent en tots els gèneres i es combina amb altres partícules; en canvi, com que és menys freqüent i apareix, sobretot, en els gèneres informals.

En els següents apartats, presentem l'anàlisi de les construccions connectives binàries en el corpus de debat parlamentari esmentat.

\section{CONNECTORS BINARIS EN EL DEBAT PARLAMENTARI}

El corpus analitzat conté 628 connectors en un total de 38762 mots ( $16 \%$ ), com es mostra desagregadament en la taula I.

\begin{tabular}{|l|c|c|c|}
\hline & Total mots & Total connectors binaris & Proporció \\
\hline Debat I & $\mathrm{I} 3738$ & 208 & $\mathrm{I} \% \% \mathrm{o}$ \\
\hline Debat 2 & 9988 & $\mathrm{I} 72$ & $\mathrm{I} 7 \% \mathrm{o}$ \\
\hline Debat 3 & $\mathrm{I} 5036$ & 248 & $\mathrm{I} 6 \% \mathrm{o}$ \\
\hline Total & 38762 & 628 & $\mathrm{I} 6 \% \mathrm{o}$ \\
\hline
\end{tabular}

Taula I. Quantitat i proporció de connectors binaris ${ }^{6}$

D'antuvi, s'observa que els tres debats contenen una quantitat similar de connectors binaris (208, I5\% \% I72, I7\%o; i 248, I6\%). Aquesta igualtat és menor si tenim en compte el parlamentari, com recull la taula 2.

6. Hi incloem les combinacions com un element connectiu, seguint la proposta de Cuenca i Marín (2009). Per exemple, la combinació $i$, per tant funciona en conjunt. Els percentatges s'han calculat tant per mil sobre el total de mots. 


\begin{tabular}{|l|c|c|c|}
\hline Parlamentari & Total mots & Total connectors & Proporció \\
\hline Oriol Junqueras(ERC) & $\mathrm{I} 768$ & 38 & $2 \mathrm{I} \% \mathrm{o}$ \\
\hline Dolors Camats (ICV) & 2775 & 56 & $20 \% \mathrm{o}$ \\
\hline Joan Herrera (ICV) & 4528 & 89 & $\mathrm{I} 9 \%$ \\
\hline Jordi Turull (CIU) & 4687 & 89 & $\mathrm{I} 9 \%$ \\
\hline Pere Navarro (PSC) & $35 \mathrm{I} 8$ & 58 & $\mathrm{I} 6 \% \mathrm{o}$ \\
\hline Marta Rovira (ERC) & 4447 & 73 & $\mathrm{I} 6 \% \mathrm{o}$ \\
\hline Oriol Pujol (CIU) & 3042 & 47 & $\mathrm{I} 5 \%$ \\
\hline Alicia Sánchez-Camacho (PPC) & $4 \mathrm{I} 59$ & 52 & $\mathrm{I} 3 \% \mathrm{0}$ \\
\hline Santi Rodríguez (PPC) & $\mathrm{I} 56 \mathrm{I}$ & $2 \mathrm{I}$ & $\mathrm{I} 3 \% 0$ \\
\hline Quim Arrufat (CUP) & 6092 & 80 & $\mathrm{I} 2 \% 0$ \\
\hline Maurici Lucena (PSC) & $2 \mathrm{I} 85$ & 26 & $\mathrm{I} 2 \% 0$ \\
\hline Total & 38762 & 628 & $\mathrm{I} 6 \% \mathrm{o}$ \\
\hline
\end{tabular}

Taula 2. Quantitat i proporció de connectors segons el parlamentari ${ }^{7}$

La quantitat de connectors per parlamentari permet dividir la totalitat de les intervencions en tres grups, segons s'aproximen més o menys a la proporció mitjana en els tres debats de I6\%o. D’una banda, és rellevant el grup que supera la proporció mitjana: la intervenció amb més connectors proporcionalment (2I \%o) és la de Junqueras, que és el text que obre el debat I, que introdueix el tema i que manifesta l'opinió acceptada per tots els partits favorables a la consulta; segueix la intervenció de Camats (20\%), les intervencions d'Herrera (19\%o) i les de Turull (19\%o), tots favorables, en general, al dret a decidir. D’una altra banda, també és destacable el grup que se situa sota la mitjana, especialment, les intervencions d'Arrufat (I2\%o) i de Lucena (I2\%o).

Podem comparar aquests resultats generals amb l'estudi més extens de Castellà (200I) sobre les construccions interordinades. El nombre de connectors que indiquen relacions binàries en l'estudi de Castellà són: 31,2\%o en la conversa informal, 13,4 \%o en la classe magistral i 9,8\% en la prosa acadèmica. ${ }^{8}$ Per tant, el corpus de debat parlamentari analitzat (amb un I6\% de connectors binaris) s'aproxima a la classe magistral $\left(\mathrm{I}_{3}, 4 \% \mathrm{\%}\right)$, que és també un text oral planificat. Podem concloure que, en general, es confirma la formalitat del debat parlamentari i la planificació prèvia, igual com ocorre amb les classes magistrals (formals i planificades).

7. El total de mots per parlamentari inclou una o dues intervencions segons els casos, excepte el cas de Quim Arrufat (CUP), que intervé en els tres debats.

8. De la mateixa manera que Castellà, hi incloem també tant els usos clausals com els textuals, perquè es manté la relació binària des del punt de vista semàntic. 
Tanmateix, cal tenir en compte les diferències individuals dels parlamentaris perquè no sempre coincideix el nombre de connectors amb la formalitat de la intervenció. Per exemple, el percentatge de Junqueras (2I \%o) s’apropa més a la conversa informal en nombre de connectors, però el text té un to formal i denota preparació. Per contra, la d'Arrufat (I2 \%o) és lleugerament propera a la prosa acadèmica tant en nombre de connectors com en el grau de formalitat. A continuació, hi ha un fragment de la intervenció de Junqueras (5) i un de la d'Arrufat (6), per a exemplificar aquestes diferències en l'estil individual.

(5) Esquerra Republicana és un partit independentista, però no demana a ningú —no demana a ningú - que sigui independentista. Òbviament, ens agradaria, convençuts com estem que tenim raons en els nostres plantejaments, que ho fos la immensa majoria de la nostra societat i que ho fossin tots els diputats d'aquest Parlament, però no demanem això. No demanem a ningú que es faci independentista. Però, en canvi, ens sembla que estem en condicions de demanar — i, si vostès m'ho permeten, gairebé d'exigir- que tots siguem demòcrates; $i$ que, per tant, tots reconeguem el dret a decidir dels nostres conciutadans. (Junqueras, ERC, DI)

(6) La construcció de la República Catalana, en el marc de la Segona República espanyola i l'anomenada "Transició democràtica», altrament coneguda com a «segona restauració borbònica», són probablement les dues grans esperances de canvi polític que ha viscut el nostre poble darrerament. La primera esperança fou esclafada directament per les armes; la segona, en el fons, va ser guanyada per les forces d'ordre i venuda per la traïció dels líders, com deixà escrit Lluís Maria Xirinacs. Partits que cridaven, abrandats, uns principis, els de l'Assemblea de Catalunya, i que, arribada l'hora de la cintura política, s'havia mogut tot perquè res en substància no es mogués: mateixos negocis, mateixa oligarquia, mateixa imposició antidemocràtica sobre els catalans i les catalanes, mateixa destrucció del territori, mateixes impunitats. (Arrufat, CUP, DI)

En (5), veiem com Junqueras usa repeticions per posar èmfasi, reformulacions, expressions metadiscursives i bastants connectors (sobretot però i per tant). En (6), en canvi, hi ha un estil més segmentat perquè només hi ha un connector (perquè), fet que aproxima la intervenció a l'escriptura.

Paral-lelament a les proporcions analitzades en la taula i i 2, les formes dels connectors també poden indicar el grau de formalitat i planificació d'un text. En la taula 3, veiem tots els connectors binaris (incloent-hi les combinacions de connectors) identificats en el corpus d'anàlisi, ordenats segons la freqüència, i dividits segons el valor semàntic del connector i de si actuen en el nivell oracional o textual. 


\begin{tabular}{|c|c|c|c|c|}
\hline Significat & Connector & Oracional & Textual & Total \\
\hline \multirow{6}{*}{ Causa } & perquè & 203 & & \multirow{6}{*}{$215(34 \%)$} \\
\hline & com que & 3 & & \\
\hline & perquè, miri & 3 & & \\
\hline & atès que & 2 & & \\
\hline & ja que & 2 & & \\
\hline & perquè, en definitiva & 2 & & \\
\hline \multirow{13}{*}{ Contrast } & però & 88 & 72 & \multirow{13}{*}{ I93 (3I \%) } \\
\hline & sinó que & I6 & & \\
\hline & però, a més & & 4 & \\
\hline & en canvi & & 2 & \\
\hline & però, en tot cas & & 3 & \\
\hline & això sí & 2 & & \\
\hline & ara & & I & \\
\hline & ara bé & $\mathrm{I}$ & & \\
\hline & mentre que & $\mathrm{I}$ & & \\
\hline & però, de la mateixa manera & & I & \\
\hline & però, en canvi & & I & \\
\hline & però, perdonin & & I & \\
\hline & tanmateix & & 23 & \\
\hline \multirow{6}{*}{ Conseqüència } & $i$, per tant & I9 & 22 & \multirow{6}{*}{ 8I $(\mathrm{I} 3 \%)$} \\
\hline & per tant & 6 & 26 & \\
\hline & doncs & 2 & 3 & \\
\hline & en conclusió & & I & \\
\hline & en definitiva & & I & \\
\hline & per conseqüència & I & & \\
\hline Condicional & si & 24 & & $74(\mathrm{I} 2 \%)$ \\
\hline \multirow{2}{*}{ Final } & perquè & 39 & & \multirow{2}{*}{$42(7 \%)$} \\
\hline & per tal que & 3 & & \\
\hline \multirow{5}{*}{ Concessiu } & però & & 9 & \multirow{5}{*}{$23(3 \%)$} \\
\hline & encara que & 8 & & \\
\hline & malgrat que & 3 & & \\
\hline & tot $i$ que & 2 & & \\
\hline & de totes maneres & & I & \\
\hline Total & & $460(73 \%)$ & I68 (27\%) & 628 \\
\hline
\end{tabular}

Taula 3. Connectors binaris en el debat parlamentari ${ }^{9}$

9. Algunes combinacions de connectors inclouen elements de tipus pragmàtic, com els verbs de percepció, que funcionen com a marcador discursiu: perquè, mirio però, perdonin. Per a més informació, consulteu Marín (2005). 
Martí Mestre

Construccions connectives binàries en el debat parlamentari

D’una banda, observem que les construccions binàries són més freqüents en el nivell oracional ( $73 \%$ dels casos), que en el textual ( $27 \%$ dels casos). Si ho comparem amb els resultats de Castellà (200I: 474), la situació és semblant perquè també hi predominen les construccions d'abast oracional en la classe magistral (IO,9\%o de I3,4\%o) i en la prosa acadèmica $(8,3 \%$ de $9,8 \%$ ), encara que, en la conversa informal, la diferència es redueix notablement ( $18 \%$ de $3 \mathrm{I}, 2 \%)$. Per tant, des d'aquest punt de vista, el debat parlamentari s'aproxima també a la classe magistral en formalitat i planificació.

Si ens fixem en els connectors identificats, hi predominen: els causals (2I5 casos, $34 \%$ ), sobretot les construccions amb perquè; els de contrast (193 casos, 31\%) amb predomini de però, seguit d'un grup intermedi format pels consecutius (8I casos, I3\%) $\mathrm{i}$, finalment, els condicionals amb (74 casos, I2 \%). Les construccions menys freqüents són les finals i les concessives ( 42 casos, $7 \%$, i 23 casos, $3 \%$, respectivament). Aquestes xifres manifesten un equilibri entre els causals (perquè), introductors d'arguments, i els de contrast (però), introductors de contraarguments. ${ }^{10}$

Veiem, a més, que els connectors més usats són sempre els mateixos (perquè, però, si, per tant), però hi ha una certa varietat de formes de connectors (perquè, atès que, com que, ja que, però, tanmateix, en conclusió, en definitiva, malgrat que, encara que, tot $i$ que, etc.) que enllaça amb el to formal d'aquest gènere i la preparació prèvia per escrit. Especialment, hi destaquen els connectors de contrast amb 9 formes (però, sinó que, en canvi, en tot cas, això sí, ara, ara bé, mentre que i tanmateix), els consecutius amb 5 formes (per tant, doncs, en conclusió, en definitiva i per conseqüència) i els concessius amb 5 formes (encara que, de totes maneres, malgrat que, però i tot i que). ${ }^{11}$ Tanmateix, la freqüència de la major part de les formes és reduïda, amb dues o tres ocurrències per forma, la qual cosa impedeix parlar de varietat de formes en sentit estricte i apropa el gènere a l'oralitat, cosa que, en sentit quantitatiu, corrobora el que apunten Castellà (200I) i Cuenca (20I3a) respecte a la varietat reduïda de connectors en els textos orals en contrast amb els escrits.

En síntesi, el debat parlamentari manifesta una freqüència de connectors binaris que es pot relacionar amb l'oral formal i planificat (en concret, s'aproxima al gènere de la classe magistral). A mesura que s'incremente o disminuïsca la quantitat de connectors, una intervenció parlamentària s'apropa més a gèneres orals com la conversa informal o, contràriament, a la prosa escrita, respectivament. Pel que fa a la freqüència

IO. En aquest cas, la comparació amb Castellà (200I: 483) no és pertinent perquè els tipus de texts són diferents: la classe magistral conté més seqüències expositives i el debat parlamentari, més d'argumentatives.

II. Les combinacions de connectors se separen quant a la forma. 
i varietat de connectors, el debat parlamentari opta pels connectors binaris causals i de contrast amb el predomini d'una mateixa forma per valor, perquè i però. Aquestes dades coincideixen amb els resultats de Cuenca i Mestre (20I5), on es comparava, entre altres coses, la varietat de connectors en les intervencions parlamentàries en català i en castellà. En aquest estudi, es demostra que el català conté una quantitat reduïda de connectors, però aquests són més variats respecte a la forma, la qual cosa l'aproxima a l'oral formal i planificat.

En l'apartat següent analitzem l'ús d'aquests connectors binaris en relació amb el caràcter argumentatiu de les estructures resultants.

\section{CONSTRUCCIONS CONNECTIVES BINÀRIES: ESTRUCTURES AR- GUMENTATIVES}

Les construccions connectives binàries tenen una funció eminentment argumentativa com a manifestació de l'esquema semàntic de causa/efecte o tesi/antítesi i l'esquema argumentatiu bàsic de tesi/argument o contraargument.

\section{I Construccions argumentatives}

En (7), hi veiem un exemple de construcció connectiva binària predominant en el debat.

(7) Tenim una obligació, com a demòcrates, de convocar la consulta que ens demanen els nostres conciutadans, perquè els demòcrates tenim l'obligació de posar a les mans dels nostres ciutadans les decisions més importants d'aquest país. (Rovira, ERC, D2)

En aquest exemple, s'hi pot observar una construcció de tipus causal amb per-

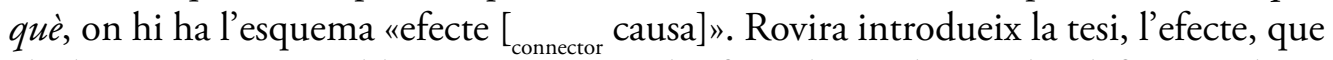
els demòcrates estan obligats a convocar el referèndum i després ho defensa amb un argument, que alhora és la causa de l'afirmació precedent, sobre el fet que la capacitat de decisió resideix en els ciutadans en una democràcia (aquest argument, per exemple, no seria vàlid per a un parlamentari que creguera en la capacitat de decisió unilateral del govern).

En (8), hi ha un exemple de construcció connectiva binària consecutiva, que és menys freqüent en el debat però és força significativa. 
Martí Mestre

Construccions connectives binàries en el debat parlamentari

(8) I és que som els ciutadans de Catalunya els que hem de decidir, però no diem en cap moment què és el que s'ha de decidir. Per tant, la vostra proposta és evident que està fora del debat d'avui, i segur — segur - que tindreu ocasió de tornar-la a plantejar en d'altres moments, i que tindrem ocasió de debatre-la, també, en altres moments. (Junqueras, ERC, Di)

En aquest cas, s'hi manifesta l'esquema «causa $\left[_{\text {connector }} \text { efecte }\right]_{» .}$ Observem com la causa «els ciutadans de Catalunya han de decidir, però no diem el què» se situa en primer lloc i funciona com a argument a la tesi, que és l'efecte «la vostra proposta està fora del debat d'avui», introduït per per tant. Aquesta opinió és del parlamentari i per això ve precedida d'un argument que la justifique (potser, per a un altre parlamentari, aquesta proposta sí que s'encabiria dins del debat d'avui).

Les construccions connectives binàries condicionals també tenen un caràcter argumentatiu, perquè introdueixen arguments i tesis, però en un marc hipotètic, no real, com en el cas de causals i concessives. Observem (9):

(9) Si no estem al seu cantó, estem equivocats, perquè vostès tenen la raó, que és la raó del poble de Catalunya. (Sánchez-Camacho, PPC, DI)

En aquest exemple, hi ha l'esquema "[ ${ }_{\text {connector }}$ causa possible], efecte possible». La causa que aporta la parlamentària "no estem al seu cantó», que significa no estar d'acord amb l'opinió del receptor, i l'efecte «estem equivocats», tenen un caràcter subjectiu, o siga, no tenir la mateixa opinió que el receptor és, segons la constatació personal, estar equivocats en el seu esquema mental de les idees ( $s$ 'ha de notar el caràcter irònic de l'estructura, perquè pensa de manera contrària). Tot amb tot, pot ser que, per a un altre parlamentari, aquesta causalitat no siga la mateixa. Vegem-ne un altre exemple en (IO):

(Io) Sies vol el federalisme, prèviament s'ha de voler el dret a decidir. (Pujol, CIU, Di)

En aquest cas, Pujol ha afirmat que el federalisme i el dret a decidir estan lligats, perquè l'un inclou l'altre, però aquesta relació causal està basada en la seua ideologia i és possible que, per a un altre parlamentari, tampoc hi haja cap relació.

De manera semblant a les condicionals, la relació causativa de les finals amb l'esquema «causa possible $\left[_{\text {connector }}\right.$ efecte possible]» fa que tinguen valor argumentatiu, encara que menys prototípic, dins del camp hipotètic o no factual. Observem (II): 
(II) No és temps d'imposició; és temps de respecte, és temps d'escoltar i és temps que la ciutadania pugui expressar la seva opinió, perquè realment aquesta negociació es doni de tu a tu i des de la voluntat de la ciutadania. (Herrera, ICV, Di)

El parlamentari creu que escoltar els ciutadans, respectar-los i deixar-los expressar-se és la causa possible perquè la negociació incloga la ciutadania, però un altre parlamentari pot pensar el contrari i, per exemple, pot afirmar que és millor la inclusió de la voluntat de les empreses. Comprovem, doncs, que tant les relacions de condició com les de finalitat són argumentatives.

Si aprofundim més en la dimensió argumentativa, les construccions connectives binàries creen unes estructures d'ordre regressiu, si s'inicia amb l'argument, o bé d'ordre progressiu, si s'inicia amb la tesi. Adam (I992) sols considera les causals i les consecutives com a estructures que creen un ordre o un altre, però nosaltres també incloem les condicionals i les finals en el present treball d'acord amb la justificació que hem fet sobre els trets eminentment argumentatius d'aquestes relacions binàries. Aquest fet es pot comprovar si convertim, per exemple, l'oració condicional en una oració causal o consecutiva. Observem l'exemple (I2):

(I2) Si volem impulsar aquests canvis a través de l'exercici del dret a decidir dels ciutadans i ciutadanes de Catalunya, cal fer-ho a través d'un referèndum acordat en el marc de la legalitat. (Navarro, PSC, Di)

Hi ha una causa possible que esdevé l'argument «impulsar els canvis a través del dret a decidir», i una tesi "cal fer-ho amb un referèndum legal», però totes dues categories dins d'un marc possible d'opinió. Tanmateix, si creem una estructura causal amb les mateixes categories, obtenim el mateix resultat però dins d'un marc real d'opinió, com ocorre en (7).

(13) Com que volem impulsar aquests canvis a través de l'exercici del dret a decidir dels ciutadans i ciutadanes de Catalunya, cal fer-ho a través d'un referèndum acordat en el marc de la legalitat.

Tenint en compte els aspectes esmentats, la tesi indica un fet previ lògicament en les construccions causals i condicionals (ordre regressiu), i un fet posterior o derivat en les consecutives i finals (ordre progressiu). En tot cas, textualment pot haver-hi una estructura amb l'ordre contrari al no marcat en els casos en què la construcció admet reversibilitat. 
Martí Mestre

Construccions connectives binàries en el debat parlamentari

Si fem una consideració general i segons els connectors binaris més freqüents en el corpus, concloem que l'ordre regressiu, més propi de l'oral, destaca en el corpus d'anàlisi pel fet que hi ha un $34 \%$ (215 casos) de construccions connectives causals i un I2\% (74 casos), de condicionals, enfront d'un $13 \%$ (8I casos) de construccions consecutives i un $7 \%$ (42 casos), de finals. En aquest sentit, el debat parlamentari s'aproxima a l'oralitat en la formalització verbal de les estructures argumentatives, que, per tenir un ordre regressiu, segueixen l'ordre lògic de l'enunciació. Per contra, les d'ordre progressiu també presenten una freqüència considerable, cosa que es justifica per la preparació prèvia per escrit d'aquest gènere.

\subsection{Estructures Contraargumentatives}

Les relacions de contrast generen unes estructures contraargumentatives en el discurs. Per exemple, en (I4), hi ha una construcció connectiva binària de contrast seguint els mateixos paràmetres que hem esmentat, però ara amb l'esquema «tesi $[\text { connector } \text { antítesi }]_{» .}$

(I4) Esquerra Republicana és un partit independentista, però no demana a ningú —no demana a ningú - que sigui independentista. (Junqueras, ERC, DI)

En el primer argument "Esquerra Republicana és un partit independentista», el parlamentari explicita les bases ideològiques del seu partit $\mathrm{i}$ això condueix cap a la conclusió «volem la independència de Catalunya». En canvi, en el segon argument, el parlamentari atribueix més força argumentativa a una idea que pot semblar contradictòria, perquè el propòsit d'un partit independentista normalment és demanar que tothom siga independentista. Veiem com la conclusió que inferim al final és que Esquerra Republicana demana que tothom defense el dret a decidir, però no que tothom siga independentista. Òbviament aquest partit sí que voldria que tothom fóra independentista, però el seu representant, conscient que això pot ser utilitzat pels adversaris per invalidar el seu discurs, ho utilitza com a contraargument.

Les construccions concessives tenen un funcionament semblant a les adversatives

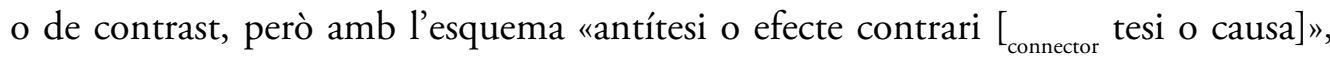
com en (I5).

(I5) Cada vegada tinc més clar que el PSC és l'únic que defensa de veritat un dret a decidir realista i possible, tot $i$ que ens oposem obertament a la independència com a solució. (Navarro, PSC, D2) 
Veiem com l'estructura s'inicia amb l'antítesi o efecte contrari i segueix amb la tesi o causa, que resulta ineficient perquè «el PSC és l'únic que defensa de veritat un dret a decidir realista i possible». La relació que hi ha entre els membres és compatible, ja que el fet de defensar el dret a decidir no implica voler la independència.

En aquestes construccions, els contraarguments corresponen a les clàusules precedides pel connector, la clàusula d'origen en el cas de les concessives, i la clàusula de la fi en el cas de les adversatives. A partir d'aquest fet, deduïm que la força argumentativa que hi ha en aquests dos tipus de relacions és diferent. Per un costat, en les estructures adversatives, el contraargument és prou potent per a poder inferir la conclusió contrària i orientar l'argumentació en un sentit, i se situa en segona posició. En les estructures concessives, el contraargument és més feble per poder inferir una conclusió determinada i no permet orientar l'argumentació en aquest sentit, i se situa, generalment, en primer lloc. ${ }^{12}$ En (I6), veiem un exemple d'estructura amb un contraargument fort.

(i6) Els socialistes de Catalunya volem que el nostre país segueixi unit a la resta d'Espanya. Però volem que l'encaix de Catalunya sigui millor, sigui un encaix federal. (Lucena, PSC, D3)

Veiem com el primer membre de l'estructura orienta cap a la conclusió «volem formar part d'Espanya de la mateixa manera» i el segon membre ens orienta cap a la conclusió «no volem formar part d'Espanya d'aquesta manera, sinó dins d'un encaix federal». El segon membre és prou potent i té la força suficient per a anul.lar l'argument anterior. En canvi, observem l'exemple d'estructura amb un contraargument feble en (I7).

(17) Els saludem i els felicitem pels avenços fets, malgrat que proposin passar per un procés previ que pot cansar el poble de forma innecessària mentre se li apliquen retallades en part fruit de la submissió a Espanya i als mercats. (Arrufat, 55)

Comprovem que el contraargument introduït pel concessiu no és prou eficient per a anul-lar el valor positiu de tots els «avenços fets», que són motiu de felicitació en lloc de reprovació.

La presència d'estructures amb contraarguments forts és preeminent en el nostre corpus, amb un total de 193 casos (3I\% del total), i això ens indica que els

I2. Besa (20I4) exposa que els connectors opositius introdueixen un contraargument fort i els connectors concessius introdueixen un contraargument dèbil. Ara bé, els connectors concessius textuals, per tal com introdueixen l'antítesi, precedeixen un contraargument fort. 
Martí Mestre

Construccions connectives binàries en el debat parlamentari

parlamentaris fan servir estratègies argumentatives més potents per orientar el seu discurs de manera sòlida i per evitar que els adversaris puguen rebatre els arguments amb facilitat. Per contra, no sols les concessives són escasses, sinó que això també fa que hi haja una presència mínima d'estructures amb contraarguments dèbils, amb sols 23 casos ( $3 \%$ del total).

Un dels fenòmens destacable tant en les estructures argumentatives com contraargumentatives és la recursivitat. En alguns casos, el segon segment de les construccions binàries està coordinat amb altres de semblants situats en el mateix nivell jeràrquic, perquè depenen del mateix segment, generalment inicial. Tanmateix, des del punt de vista argumentatiu, interessen les construccions amb recursivitat cíclica, o estructures doblement binàries, que són les construccions bimembres que contenen una altra estructura, que alhora també presenta una relació binària des d'una perspectiva semàntica i estructural. Aquesta segona estructura té un rang menor perquè es troba en un altre nivell jeràrquic: és a l'interior d'una part de l'altra i té un significat en conjunt; és la causa o l'efecte, la tesi o l'antítesi. Observem l'exemple (I8).

(I8) I és que som els ciutadans de Catalunya els que hem de decidir, però no diem en cap moment què és el que s'ha de decidir. Per tant, la vostra proposta és evident que està fora del debat d'avui, i segur — segur - que tindreu ocasió de tornar-la a plantejar en d'altres moments, i que tindrem ocasió de debatre-la, també, en altres moments. (Junqueras, ERC, DI)

Veiem com hi ha una estructura binària de causa/efecte real, on es destaca l'efecte introduït amb per tant; al seu torn, la causa es compon d'una tesi i d'una antítesi introduïda per però.

Per a sintetitzar i clarificar aquest exemple, observem la figura 3, on hem fet una paràfrasi i es veuen de manera esquemàtica els components d'aquesta estructura doblement binària. 


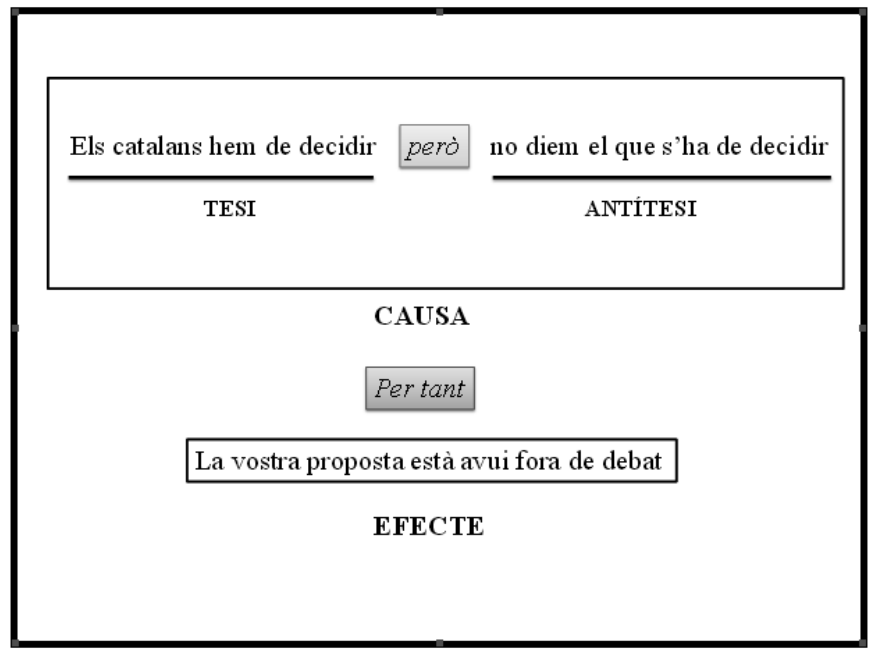

Figura 3. Estructura doblement binària

Des del punt de vista argumentatiu, es creen unes estructures més complexes perquè, en uns casos, hi ha la presència del contraargument situat en posició immediatament posterior a l'argument, seguit de la conclusió, com en (I8). Això ens indica la voluntat dels parlamentaris d'esmentar els contraarguments a l'opinió que defensen com una estratègia de prevenció.

En definitiva, hem comprovat com l'esquema semàntic de causa/efecte i de tesi/ antítesi es pot aplicar a l'estructura bàsica de l'argumentació. La tria de construcció connectiva binària té repercussions discursives en l'ordre argumentatiu. En aquest cas és majoritàriament regressiu pel fet que hi ha més construccions causals, cosa que aproxima el gènere del debat parlamentari al procés de producció i de formalització verbal dels textos orals. En el cas de la contraargumentació, hi ha una preferència per l'ús de construccions amb connectors adversatius, o de contrast en general, de manera que els contraarguments són majoritàriament forts.

\section{CONSTRUCCIONS CONNECTIVES BINÀRIES: ENCADENAMENT I DISCURS ARGUMENTATIU}

En l'anàlisi anterior, ens hem centrat en els connectors que expliciten relacions binàries i en les estructures argumentatives que generen, però ara eixamplem l'estudi 
Martí Mestre

Construccions connectives binàries en el debat parlamentari

i les examinem integrades en el discurs, en el nivell textual. Hem dut a terme una anàlisi de l'encadenament argumentatiu, basat en la proposta d'Adam (I992), d'un fragment representatiu de les intervencions de cada parlamentari, però sols hem utilitzat el debat I, perquè és el primer debat sobre el dret a decidir i és on cada portaveu planteja clarament la postura del seu partit. En l'exemple (19), hi veiem un fragment representatiu de la intervenció de Joan Herrera (ICV).

(19) Primer element, per què el volem exercir? Doncs, mirin, no el volem exercir ni per caprici ni per deliri. El volem exercir perquè hi ha un esgotament de les relacions amb l'Estat, perquè vam treure conclusions de la sentència, perquè hi ha hagut un intent de federalitzar Espanya per la via de l'acord en múltiples ocasions i perquè vam concloure, després de la sentència del 20IO, que precisament l'exercici del dret a decidir era la manera de fer un pas endavant. Perquè aquella sentència va significar el menysteniment de la voluntat de la ciutadania de Catalunya expressada en un referèndum; ho va escriure en Pérez Royo. Perquè el catalanisme sempre ha intentat avançar en el marc de la Constitució, i aquella sentència va significar trencar precisament amb una tradició del catalanisme. I perquè després, a més, han vingut reials decrets de recentralització, atacs a la llengua, l'incompliment de l'addicional tercera, la no-predisposició al pacte fiscal.

Mirin, després d'aquella sentència, el Govern d'aleshores —el Govern d'aleshores-, en aquella nova dinàmica, va plantejar acords per refer el pacte, per refer allò que havia destrossat la sentència del 20IO. I què ens vam trobar? Què es va trobar el Govern d'aleshores? Vostès ho saben prou bé: es van trobar el silenci o la indiferència del Govern també d'aleshores que hi havia a Madrid, el Govern de Zapatero i de Rubalcaba.

I és des d'aleshores que la majoria de la societat catalana va entendre, en definitiva, que no ens podíem quedar amb els braços creuats. La majoria de la societat catalana rebutja el marc estatutari, el marc constitucional que deriva d'aquella sentència. Independentment del futur que vulgui per al país; però aquesta és la majoria que s'expressa, i també la majoria que s'ha expressat en el carrer, on hi ha un sentiment majoritari a favor del dret a decidir.

En aquest exemple, Herrera manifesta una postura molt ferma quant al tema de debat: una defensa clara per part d'Iniciativa per Catalunya i els Verds del dret a decidir. En la figura 4, hi veiem l'esquema de l'encadenament argumentatiu aplicat al fragment. 

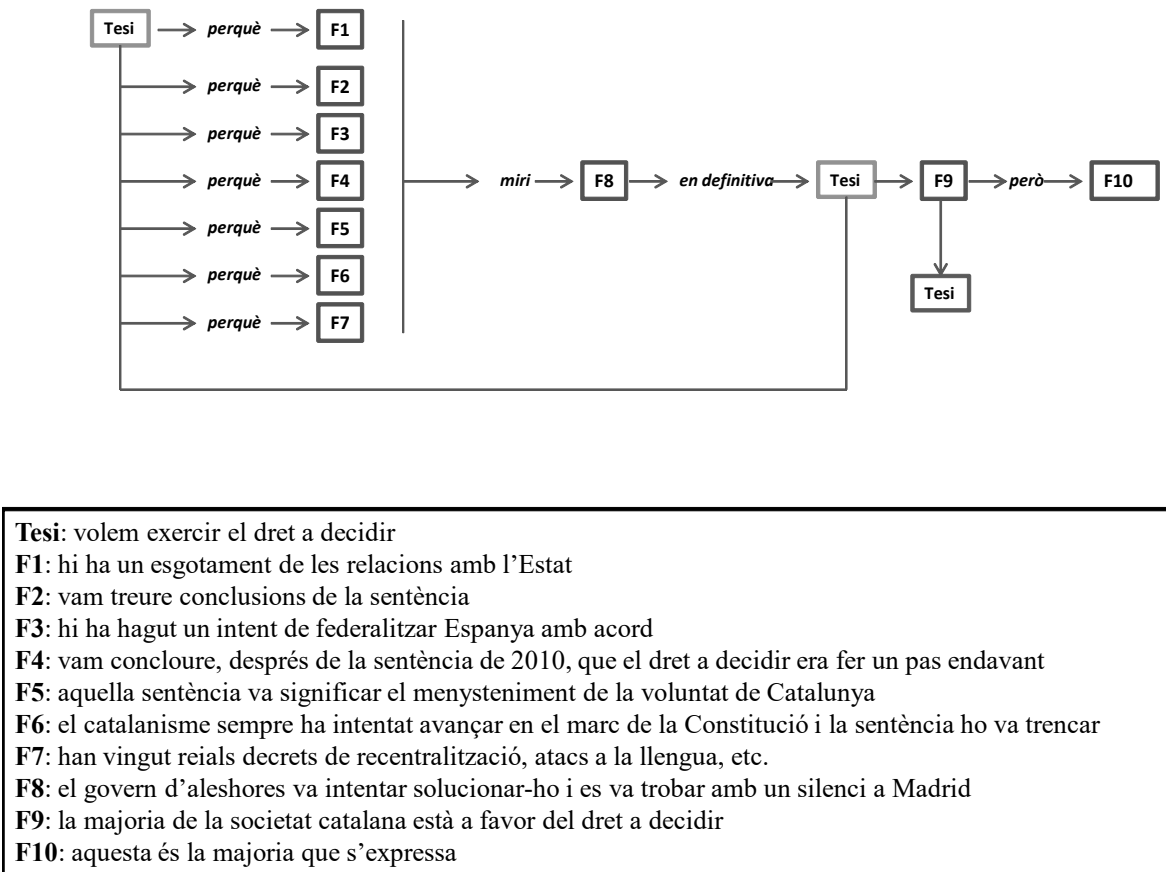

Figura 4. Esquema de l'encadenament argumentatiu de Joan Herrera

Aquest esquema mostra que l'encadenament argumentatiu de la intervenció d'Herrera és d'ordre regressiu, i els moviments són de causa/justificació, perquè hi ha una tesi o opinió i tot un seguit de fets introduïts per perquè, que serveixen com a arguments, però hi ha pocs arguments de contrast. Ara bé, en l'últim paràgraf, aquest encadenament és d'ordre invers perquè hi ha una combinació de conseqüència, que torna a introduir la tesi general amb alguns canvis, la qual cosa ens permet afirmar que el fragment és circular perquè s'ha iniciat i s'ha acabat amb la mateixa idea. Tot i ser un discurs reiteratiu per la recursivitat lineal, podem dir que és el discurs organitzat de la manera més lògica, des del punt de vista argumentatiu i des del punt de vista del canal, l'oral.

En la taula 4, veiem una síntesi de l'anàlisi de l'encadenament argumentatiu en les intervencions de cada parlamentari. 
Martí Mestre

Construccions connectives binàries en el debat parlamentari

\begin{tabular}{|c|l|c|c|c|c|}
\hline $\begin{array}{c}\text { Parlamentari } \\
\text { (Grup) }\end{array}$ & Posició & Tesi & Ordre & Moviment & Apuntalament \\
\hline $\begin{array}{c}\text { Oriol Junqueras } \\
\text { (ERC) }\end{array}$ & Favorable & $\begin{array}{c}\text { El dret a decidir } \\
\text { és democràtic }\end{array}$ & Progressiu & $\begin{array}{c}\text { Consecutiu i } \\
\text { oposició }\end{array}$ & $\begin{array}{c}\text { Principi de demo- } \\
\text { cràcia }\end{array}$ \\
\hline $\begin{array}{c}\text { Pere Navarro } \\
\text { (PSC) }\end{array}$ & Contrària & $\begin{array}{c}\text { La solució és } \\
\text { l'estat federal }\end{array}$ & Regressiu & $\begin{array}{c}\text { Causa i opo- } \\
\text { sició }\end{array}$ & $\begin{array}{c}\text { Principi de lega- } \\
\text { litat (la Consti- } \\
\text { tució) }\end{array}$ \\
\hline $\begin{array}{c}\text { Alicia Sánchez- } \\
\text { Camacho (PPC) }\end{array}$ & Contrària & $\begin{array}{c}\text { El dret a decidir } \\
\text { és il-legal }\end{array}$ & Regressiu & $\begin{array}{c}\text { Causa i opo- } \\
\text { sició }\end{array}$ & $\begin{array}{c}\text { Principi de civis- } \\
\text { me i de la legalitat }\end{array}$ \\
\hline $\begin{array}{c}\text { Joan Herrera } \\
\text { (ICV) }\end{array}$ & Favorable & $\begin{array}{c}\text { La majoria de la } \\
\text { societat defensa el } \\
\text { dret a decidir }\end{array}$ & Regressiu & Causa & $\begin{array}{c}\text { Principi de la } \\
\text { injustícia legal }\end{array}$ \\
\hline $\begin{array}{c}\text { Quim Arrufat } \\
\text { (CUP) }\end{array}$ & Favorable & $\begin{array}{c}\text { El procés presenta } \\
\text { mancances }\end{array}$ & Progressiu & Consecutiu & $\begin{array}{c}\text { Principi de la } \\
\text { voluntat popular }\end{array}$ \\
\hline $\begin{array}{c}\text { Oriol Pujol } \\
\text { (CiU) }\end{array}$ & Favorable & $\begin{array}{c}\text { El dret a decidir } \\
\text { és democràtic }\end{array}$ & Regressiu & $\begin{array}{c}\text { Causa i opo- } \\
\text { sició }\end{array}$ & $\begin{array}{c}\text { Principi de demo- } \\
\text { cràcia }\end{array}$ \\
\hline
\end{tabular}

Taula 4. Síntesi de les característiques de cada intervenció

En primer lloc, la majoria dels discursos presenten un ordre regressiu perquè hi apareixen de primer les tesis i després els arguments, majoritàriament introduïts per perquè, però és corrent que hi trobem estructures progressives, de caràcter local, amb connectors de conseqüència, que capgiren l'encadenament en un punt determinat del discurs. Aquesta anàlisi confirma el que hem apuntat en l'anàlisi local i estableix l'ordre regressiu com a predominant en el debat parlamentari, tot i tenir una preparació prèvia per escrit, però això no implica que el procés de raonament previ a la formalització verbal haja estat també regressiu. Els discursos amb un ordre progressiu, especialment el d'Arrufat, denoten trets més propis d'un text escrit que d'un discurs oral, la qual cosa també es pot demostrar amb la freqüència de connectors, que sempre són els mateixos. Tanmateix, la intervenció de Junqueras presenta un nombre de connectors més proper a la conversa informal, però alhora manté un to formal i segueix l'ordre progressiu, cosa que es justifica per l'estil individual del parlamentari.

En segon lloc, l'ordre regressiu fa que els moviments argumentatius siguen de causa/justificació/explicació, la qual cosa demostra el caràcter argumentatiu d'aquest tipus d'estructures com han apuntat Keren-Portnoy, Parush i Schlesinger (200I: 80) i contradiu la tesi de Moeschler (I985: I34). Els moviments opositius, que serveixen per a avançar-se amb contraarguments a la rebatuda dels altres, són gairebé presents en 
totes les intervencions independentment de la ideologia o posició respecte al tema de debat, excepte en el cas d'Arrufat, però de manera desigual, ja que les intervencions de Junqueras, Navarro i Sánchez-Camacho en contenen més que les d'Herrera i de Pujol. Finalment, és interessant veure com els dos partits més favorables a la proposta, CIU i ERC, es basen en el principi de la democràcia, de caire més filosòfic i moral, i els dos partits més reticents o contraris, PSC i PPC, ho fan amb el principi de la llei, més empíric i favorable a la postura dels partits majoritaris en el govern de Madrid. Uns apel-len als deures morals i democràtics i els altres a l'obligació de complir la llei. Aquest apuntalament argumentatiu situa la base de les relacions de coherència de totes les intervencions $i$, juntament amb l'anàlisi de l'encadenament argumentatiu, permet valorar l'estil discursiu de cada parlamentari en relació a l'organització i relació de les idees. En aquest sentit, podem afirmar que els discursos de Sánchez-Camacho i, sobretot el de Pujol, no estan ben organitzats i són poc eficients argumentativament. Veiem l'exemple (20) de Sánchez-Camacho.

(20) Haig de dir-li, a més, que vostè ha actuat de manera covarda, perquè, si vostè hagués volgut, a través dels mecanismes constitucionals, exercir la modificació de la Constitució, hauria fet el que va fer el senyor Ibarretxe i hauria anat a modificar el que ha de modificar amb les majories amb què les ha de fer. Saben què succeeix? Que, com allà no té les majories que ell vol, llavors ja no li serveixen. Com no li serveix la legalitat espanyola al senyor Junqueras. Aquesta és la democràcia? Escollir la cambra a què vull anar, escollir la legalitat que vull tenir? També els catalans escolliran quines lleis volen que se'ls apliquin i quines altres que no. Perquè, si vostès, que han de donar exemple, escullen, aquí escull tothom. No, no..., el sistema democràtic i l'estat de dret són per a tothom i són per complir-los. (Sánchez-Camacho, PPC, Di)

En aquest fragment, la qualitat argumentativa és feble, perquè Sánchez-Camacho utilitza consideracions interpersonals ("ha actuat de manera covarda») com a tesis $\mathrm{i}$ arguments en defensa de la tesi general sobre el compliment de la llei, i connecta idees repetides o sense sentit com «si vostès escullen, aquí escull tothom» 0 «si vostè hagués volgut [...] exercir la modificació de la Constitució, [...] hauria anat a modificar el que ha de modificar». A més, hi ha interferències en la progressió de les idees, perquè intercala els arguments introduïts per perquè amb estructures condicionals "perquè, si vostès...», cosa que entrebanca la comprensió i l'efectivitat del text. També hi ha molts fets que no estan connectats, cosa que dificulta l'encadenament de les idees, perquè aquest fragment és més espontani i la parlamentària no segueix tant el discurs preparat com la resta. Amb tot, gràcies a l'apuntalament argumentatiu, es pot dotar de coherència a algunes relacions que, a priori, no en tenen.

Caplletra 60 (Primavera, 2016), pp. 83-111 
Martí Mestre

Construccions connectives binàries en el debat parlamentari

L'exemple de Sánchez-Camacho o la intervenció de Junqueras són una mostra de la importància de l'estil individual en el gènere discursiu del debat parlamentari, ja que els investigadors poden abstraure o generalitzar els fenòmens dels corpus, com, en el nostre cas, amb l'estudi de l'ordre, els moviments i l'encadenament argumentatiu, entre altres coses, però la capacitat que tenen els parlamentaris de personalitzar lingüísticament i estilísticament les seues intervencions dificulta l'establiment d'uns resultats rotunds i clarificadors.

\section{CONCLUSIÓ}

En aquest treball hem analitzat les construccions connectives binàries presents en un corpus de debats parlamentaris sobre el dret a decidir del Parlament de Catalunya. L'anàlisi mostra que en el debat són freqüents els connectors binaris causals, amb perquè, i els d'oposició, amb però; a més, s'ha observat una certa variació de formes en alguns casos, que denota una preparació prèvia, però amb una freqüència marginal. Els debats del corpus d'anàlisi també presenten patrons de freqüència similars respecte a la totalitat de mots ( $15 \%$, I6\%o i $17 \%$ ).

Les construccions connectives resultants, basades en l'esquema semàntic de causa/ efecte o tesi/antítesi, funcionen com un mecanisme per a justificar la postura respecte al tema de debat, seguint l'ordre regressiu i amb moviments de causa/justificació, o per desmuntar les opinions dels adversaris, amb estructures amb contraarguments forts i moviments d'oposició. Amb tot, l'efectivitat argumentativa i la qualitat discursiva depenen de l'estil individual de cada parlamentari, perquè l'anàlisi ha demostrat que les intervencions presenten diferències en la construcció del discurs i en la coherència de les idees, sovint deficients.

A través de la comparació dels nostres resultats amb els de Castellà (200I), hem constatat que, pel que fa a l'ús de connectors, el gènere del debat parlamentari s'aproxima a la classe magistral, ja que presenta un nombre semblant de construccions binàries amb connector: una mitjana de $16 \%$ en el debat i i $3,4 \%$ en la classe magistral. Aquestes dades confirmen les similituds entre ambdós gèneres: són textos orals que s'han preparat prèviament per escrit però que s'intenta que tinguen trets clars d'oralitat i, en general, no són llegits, o no de manera estricta. Tanmateix, hi ha intervencions que s'aproximen en nombre de connectors a la conversa informal, com la de Junqueras (2I \%o), o als gèneres escrits, com la d'Arrufat (I2\%o).

Martí Mestre

Sveučilište u Zadru (Universitat de Zadar) marmesme@alumni.uv.es 


\section{REFERÈNCIES BIBLIOGRÀFIQUES}

AdAm, Jean-Michel (1992) Les textes: types et prototypes, París, Nathan. [Citem per la 3a edició, París, Armand Colin, 20II.]

Anscombre, Jean-Claude (I989a) «Théorie de l'argumentation, topoï, et structuration discursive», Revue québécoise de linguistique, I8/I, pp. 13-55.

—(1989b) "Argumentativity and informativity», dins Michel Meyer (ed.), Methaphysics to Rhetoric, Dordrecht, Boston/Londres, Kluwer, pp. 7I-87.

Anscombre, Jean-Claude \& Oswald Ducrot (1989) L'argumentatin dans la langue, París, Mardaga.

Apothéloz, Denis \& Denis MiÉville (1989) «Matériaux pour une étude des relations argumentatives», dins Christian Rubattel (ed.), Modèles du discours. Recherches actuelles en Suisse romande, Berna, Peter Lang, pp. 247-260

Bassols, Margarida \& Anna M. Torrent (1996), Models textuals, Barcelona, EumoOctaedro.

Bayley, Paul, ed. (2004) Cross-cultural Perspectives on Parliamentary Discourse, Amsterdam, John Benjamins.

BesA, Josep (20I4), Els textos argumentatius, Barcelona, Santillana Grup Promotor.

Calsamiglia, Helena \& Amparo Tusón (1999) Las cosas del decir. Manual de anàlisis del discurso, Barcelona, Ariel.

CASTELlÀ, Josep M. (200I) «La complexitat lingüística en el discurs oral i escrit: densitat lèxica, composició oracional i connexió textual», tesi doctoral, Barcelona, Universitat Pompeu Fabra

- (2004) Oralitat i escriptura. Dues cares de la complexitat del llenguatge, Barcelona, Curial / Publicacions de l'Abadia de Montserrat.

Corminbreuf, Gilles (20IO) «La causalité sans les connecteurs "causaux" Préalables épistémologiques", Linx, 62/63, pp. 39-62.

Cuenca, M. Josep (1988) L'oració composta (I): la coordinació, València, Publicacions de la Universitat de València.

- (I99ia) L'oració composta (II): la subordinació, València, Publicacions de la Universitat de València.

- (1991b) Les oracions adversatives, Barcelona/València, Publicacions de l'Abadia de Montserrat / Institut de Filologia Valenciana.

- (1995) «Mecanismos lingüísticos y discursivos de la argumentación», Comunicación, Lenguaje y Educación, 26, pp. 23-40.

- (2006) La connexió i els connectors, Vic, Eumo. 
Martí Mestre

Construccions connectives binàries en el debat parlamentari

- (2013a) "Causal constructions in speech», dins C. Bolly \& L. Degand (eds.), TextStructuring. Across the Line ofSpeech and Writing Variation (Corpora and Language in $U s e)$, 2, Louvain-la-Neuve, Presses Universitaires de Louvain, pp. I7-3I.

- (2013b) «The fuzzy boundaries between discourse marking and modal marking», dins Liesbeth Degand, Bert Cornillie \& Paola Pietrandrea (eds.), Discourse Markers and Modal Particles: Categorization and description, Amsterdam, John Benjamins, pp. I9I-216.

- (2014) «The use of demonstratives and context activation in Catalan parliamentary debate ", Discourse Studies, I6 (6), pp. 729-752.

Cuenca, M. Josep \& M. Josep Marín (2009) «Co-occurrence of discourse markers in Catalan and Spanish oral narrative», Journal of Pragmatics, 4 (I), pp. 899- 9I4.

Cuenca, M. Josep \& Martí Mestre (en premsa) «Use of connectives and argumentation in Catalan parliamentary debate».

Degand, Liesbeth (1998) «On classifying connectives and coherence relations», Proceedings of COLING-ACL Workshop on Discourse Relations and Discourse Markers, Montréal, pp. 29-35.

Ducrot, Oswald (1984) Le dire et le dit, París, Minuit.

Ellerup Nielsen, Anne (1996), "The argumentative impact of causal relations», Argumentation, Io (3), pp. 329-345.

García Berrio, Antonio (1970) «Bosquejo para una descripción de la frase compuesta en español», Anales de la Universidad de Murcia, XxvIII, 3/4, pp. 209-23I.

GoHL, Christine (2000) «Causal relations in spoken discourse: asyndetic constructions as means for giving reasons", dins Elizabeth Couper-Kuhlen \& Bernd Kortmann (eds.), Cause, Condition, Concession, Contrast. Cognitive and Discourse Perspectives, Berlin, New York, Mouton de Gruyter, pp. 83-IIo.

ILIE, Cornelia (2003) «Discourse and metadiscourse in parliamentary debates», Journal of Language and Politics, I (2), pp. 71-92.

- (2006) «Parliamentary Discourses», dins Keith Brown (ed.), Encyclopedia of Language and Linguistics, Oxford, Elsevier, vol. 9, I88-197.

Keren-Portnoy, Tamar, Tamar Parush \& Izchak Schlesinger (200I), The structure of Arguments, Amsterdam, John Benjamins.

López GARCíA, Ángel (1983), «Las conjunciones y la oración compuesta», dins Estudios de lingüistica española, Barcelona, Anagrama, pp. 43-65.

Marafioti, Roberto (2007) «Discurso parlamentario: entre la política y la argumentación», dins Roberto Marafioti (ed.), Parlamentos: teoría de la argumentación $y$ debate parlamentario, Buenos Aires, Biblos, pp. 93-I27. 
Marín, M. Josep (2005) Marcadors discursius procedents de verbs de percepció. Argumentació implícita en el debat electoral, València, Universitat de València, Annex 59 de Quaderns de Filologia.

Mestre, Martí (20I4) «Construccions connectives binàries en el debat parlamentari», treball fi de màster, València, Universitat de València.

Moeschler, Jacques (1985), Argumentation et conversation, París, Hatier-Crédif.

(1989) «Pragmatic connectives, argumentative coherence and relevance», Argumentation, 3 (3), pp. 32I-339.

- (2015) «How do discourse connectives constrain argumentation and utterance interpretations», dins J. Capone \& J. Mey (eds.), Interdisciplinary Studies in Pragmatics, Culture and Society, Dordrecht, Springer, vol. 4., cap. 26.

Rojo, Guillermo (1978), Cláusulas y oraciones, Santiago de Compostel.la, Annex I4 de Verba.

SANDERs, Ted \&Wilbert Spooren (2009) «Causal Categories in discourse. Converging evidence from language use», dins Ted Sander \& Eve Sweetser (eds.), Causal Categories in Discourse and Cognition, Berlin / New York, Mouton de Gruyter, pp. 205-244.

Toulmin, Stephan (1958), The Use of Arguments, Cambridge, Cambridge University Press. [Citem per la Ia edició actualitzada (2003).]

VAN Dijk, Teun A. (1978), La ciencia del texto, Barcelona, Paidós.

- (1993), "Principles of Critical Discourse Analysis», Discourse and Society, 4 (2), pp. 249-283.

- (2000), «Parliamentary discourse», dins Teun A. Dijk \& Ruth Wodak (eds.), Racism at the Top. Parliamentary Discourses on Ethnic Issues in Six European States, Klagenfurt, Drava, pp. 45-78.

- (2002) "Political discourse and ideology», dins Clara Ubaldina \& Montserrat Ribas (eds.), Anàlisi del discurs polític. Producció, mediació i recepció, Barcelona, Universitat Pompeu Fabra, pp. 15-34. 